\section{Taking Care of the Sick and Scared}

\section{A Local Response in Pandemic Preparedness}

\author{
Marcia M. Johnson, MD, MHSc, FRCPC ${ }^{1}$ \\ Eric A. Bone ${ }^{2}$ \\ Gerry N. Predy, MD, FRCPC ${ }^{3}$
}

\section{SUMMARY}

Virtually all health care operations, including public health, are undertaken only at a local or regional level. Large-scale infectious disease emergencies, such as SARS or pandemic influenza, will be recognized and managed at a local level. The creation of the Public Health Agency of Canada (PHAC) was an important step in strengthening public health capacity. However, we need adequate operational capacity in local public health departments to have a strong public health system.

Local public health takes an integral role in the preparation for and management of infectious disease emergencies. Local public health departments and regional public health infrastructures must be positioned to both maintain core functions and to lead and support health sector response to emergencies. The local establishment of a flexible and sustainable emergency management system must address the need to:

- integrate health care and first responders;

- provide all-hazards tools for managing a crisis at the frontline;

- rank service priorities and provide surge resources; and

- provide accurate information on a timely basis

Only the leaders within the local or regional health care facilities and organizations can develop workable plans to deliver health care. PHAC must ensure and support the local public health infrastructure and local emergency preparedness. Without this support, there will be consequences for local response to major public health emergencies.

\section{ABRÉGÉ}

Pratiquement toutes les mesures relatives aux soins de santé, y compris les mesures de santé publique, ne sont prises qu'au palier local ou régional. Les éclosions de maladies infectieuses à grande échelle comme le SRAS ou la grippe pandémique sont des urgences sanitaires détectées et gérées à l'échelle locale. La création de l'Agence de santé publique du Canada (ASPC) a beaucoup contribué à renforcer les capacités en santé publique, mais pour assurer la solidité du réseau, il faut prévoir une capacité opérationnelle suffisante au niveau des services locaux.

Ces services locaux de santé publique font partie intégrante de la préparation aux urgences relatives à des maladies infectieuses, puis à la gestion des interventions. Les services locaux et les infrastructures régionales de santé publique doivent être en mesure de continuer à assurer les fonctions de base tout en dirigeant et en appuyant les interventions sanitaires d'urgence. Un système local de gestion des urgences à la fois souple et durable suppose donc :

- une action intégrée des dispensateurs de soins de santé et des secouristes opérationnels;

- des outils « tous risques» pour la gestion des crises aux premières lignes:

- I'établissement des priorités en matière de services et l'existence de ressources d'appoint;

- la prestation de renseignements exacts en temps utile.

Seuls les dirigeants des établissements et des organismes de santé locaux et régionaux peuvent élaborer des plans viables en matière de prestation des soins de santé. L'ASPC doit renforcer et soutenir les infrastructures locales en santé publique et la préparation locale aux situations d'urgence. Sans cet appui, les mesures locales risquent d'être inadéquates lors d'une grave urgence de santé publique.

Capital Health, Edmonton, $\mathrm{AB}$

1. Deputy Medical Officer of Health

2. Senior Planner, Office of Emergency Preparedness

3. Medical Officer of Health, Public Health Division

Correspondence and reprint requests: Dr. Marcia M. Johnson, Deputy Medical Officer of Health, Capital Health, Suite 300, 10216-124 Street, Edmonton, AB T5N 4A3, Tel: 780-413-7601, Fax: 780-413-7950, E-mail: mjohnson@cha.ab.ca
T he post-SARS federal commitment to improving public health infrastructure in Canada was reassuring to both the public and health care workers. The subsequent establishment of the Public Health Agency of Canada is a hopeful step. However, the reinvestment in public health infrastructure at the local level is uneven at best and we believe it is the local or regional preparedness that is the key to an effective emergency management in health care in all large-scale emergencies, but particularly in infectious disease emergencies, including pandemic influenza. As Naylor so aptly noted:

"Even greatly enhanced technical support and outbreak investigation by a federal agency will be somewhat irrelevant if the local and regional capacity for outbreak response is weak".

Large-scale infectious disease emergencies such as SARS or pandemic influenza will be recognized and managed at a local level. Individual cases will present to local physicians or emergency departments, specimens will be collected and processed locally, cases will receive care locally and the impact of societal changes will be experienced at local/regional level. In fact, virtually all health care operations, including public health, are undertaken only at a local or regional level.

Local public health departments and public health infrastructure within a region must be positioned to maintain core functions as well as to lead and support health sector response to emergencies. Core public health functions, such as surveillance, prevention of the spread of disease by use of quarantine and isolation orders under the authority of Medical Officers of Health, provision of immunizations and assurance of safety of essential services such as water and food, will be critical. Public Health's increasing involvement with infection control and emergency preparedness across Canada adds to the integral role local Public Health must play in the preparation for and management of infectious disease emergencies.

\section{Surveillance}

Surveillance is the cornerstone of any strategy to mitigate the devastation of an infectious disease pandemic. The timely recognition of the occurrence of specific illnesses in a population may allow implementation of control activities to slow the spread 
and attenuate the rapidity of development of new cases. Surveillance activities require alert clinicians combined with robust and timely laboratory diagnostics networked with infection control teams and public health partners.

"....all preparedness ultimately is local... it is the local Public Health Department, the local healthcare organizations, and importantly the local clinicians and laboratories who are our strongest link, but each can't do this alone. Their strength comes from their connectivity". ${ }^{2}$

While the short incubation period and the expected high transmission rate of influenza may preclude the usefulness of quarantine (sequestering of well people exposed to a case of a communicable disease) and isolation during an influenza pandemic, these control strategies are traditional tools implemented on the authority of Medical Officers of Health and may prove to be key in situations such as smallpox or SARS. Accurate, timely case identification and outcome data collected locally will be the only source of meaningful information to both inform health resource management locally and to be transmitted to provincial, federal and subsequently international levels.

\section{Mass immunization}

Public Health has traditionally organized and delivered mass immunization campaigns, often with health care partners. The widespread use of antiviral medication, as suggested for pandemic influenza, will be a new challenge requiring creativity and leadership. The assumed shortfall of such medication requires prior ethical discussions and planning within health care and between health care and the public, particularly those providing essential societal functions. These discussions are needed at all organizational levels.

\section{Need to integrate health care and first responders}

The hard lessons learned in the fall of 2001 by the paradigm-shifting tragedy of the twin towers included the concept that emergency preparedness is a necessity in health care. The subsequent flurry of white powder incidents across North America, including virtually every health jurisdiction in Canada, demonstrated that integration of emergency responses between health care organizations and municipal first response services such as fire, police and ambulance is required for effective emergency management. Public Health carries a tradition of involvement with municipalities. All these lessons and more were driven home in Canada by SARS in the spring of 2003.

Robust emergency preparedness mandates local establishment of a flexible and sustainable emergency management system such as Incident Command System (ICS). ${ }^{3}$ Such a structured approach would provide unity and a leadership chain of command, administrative and financial management of the response, information collection, documentation and dissemination. It supplies an all-hazards tool for managing a crisis situation locally and provides timely and locally relevant information to people managing the crisis at the front line. Clarity of roles and responsibilities preevent is essential both within a region or health care organization and externally with local partners, the province and the federal government. An office of emergency preparedness also proves to be an invaluable port of contact and cooperation for others involved in community-wide emergency response such as municipalities and large employers.

\section{Rationing health care}

Pandemic influenza looms near with its twinned challenges to health service delivery: increased demand and concurrent decreased health work force. It is assumed pandemic influenza will overwhelm local health care's ability to meet usual demand and definitive care or usual care will need to be rationed. ${ }^{4}$ However, it is essential that planning be undertaken to identify or develop surge resources (i.e., alternate equipment, locations and personnel needed to maintain a standard of care) in order to maintain effective service for as long as possible. While activities such as stockpiling of antiviral medication and policy developmentregarding priority groups for the expected limited medication and vaccine supply should be made at federal and provincial levels, it is only the leaders within the local or regional health care facilities and organizations who can develop workable plans to deal with the ability to deliver health care.

Pandemic planning at the local or regional level is as much about what will not be doable as it is about what can be done. Obviously, in an extreme crisis - as will be presented by pandemic influenza health services will have to be prioritized. One approach utilizes the concept of a maximum tolerable downtime (MTD)5. An MTD is the maximum length of time a service can be safely suspended, but also includes a ranking for services which are expected to require more resources than normal. For example, during a pandemic, emergency department services may need to be increased whereas prenatal education may be deferred for 5 to 6 weeks. Ranking services in this way provides a template to guide local or regional response to demand surge and associated staff reallocations. More important, perhaps, is the local exercise of having managers and health care professionals sitting together and undertaking the hard discussions required to reach a consensus on priorities of each locally provided health service. Such discussions will build networks of understanding regarding the expected challenges and planned response. The resulting relationship building and shared expectations will likely prove to be the true value in local pandemic preparedness planning.

"In preparing for battle, I have always found that plans are useless but planning is indispensable". ${ }^{6}$

Dwight D. Eisenhower

\section{Communication}

Communication of accurate information on a timely basis is another important aspect of the pandemic response. A detailed communication plan is essential at a local level, including robust communication strategies to share timely information both internally within health care and externally to partners and the public. The plan should identify credible spokespersons, who can communicate openly to the public and providers. Local public health departments need to build upon the networks they use in their day-to-day work. This includes laboratories, emergency departments and primary care providers. They need to leverage technology to ensure a capacity to deliver messages effectively. Technologies include websites and e-mail as well as landline, cellular and satellite telephones. However, telephone communication may well fail during an emergency. A back-up radio-based system or similarly robust technology is also a requirement. 
The creation of the Public Health Agency of Canada was an important step in strengthening public health capacity. However, without adequate operational capacity in local public health departments, a strong federal agency will not be significant value added. One of the roles of the Public Health Agency must be to ensure and support the local public health infrastructure and local emergency preparedness.
Without this support, we will not be optimally prepared to deal with major public health emergencies.

\section{REFERENCES}

1. Naylor D. A report of the National Advisory Committee on SARS and Public Health, October 2003.

2. Gerberding J. Director CDC, presentation at First National Congress on PH Readiness. July $20-22,2004$

3. Incident Command System Orientation: 1-100, study guide, emergency management - British
Columbia. I. Justice Institute of British Columbia Emergency Management Division Student Manual, April 2002.

4. Riccaforte DJ, Arbenz EJ. Surge Capacity and Disaster Preparedness for Definitive Care Areas. "Sphere" J NY State Soc Anesth 2005;57(1):5368.

5. MTD (Maximum Tolerable Downtime) Roessing, Rolf von - Auditing Business Continuity: Global Best Practices - 2002.

6. Eisenhower DD (1890-1969), U.S. general, Republican politician, president. Quoted by Richard Nixon in "Krushchev," Six Crises (1962)

\section{The Top 10 poor excuses for NOT getting the flu shot:}

10. you think aches, pains \&e fever are underrated

9. you're desperate for a little sympathy

8. you'd like to catch up on the TV soaps

7. you want to keep your colleagues at bay

6. you like your voice a little raspy

5. you get thrills from having the chills

4. you'd like some time away from the office

3. your stock portfolio includes Kleenex ${ }^{\circledR}$

2. you consider coughing a full body workout

AND THE \#1 POOR EXCUSE FOR NOT GETTING THE FLU SHOT IS...

1. you don't really care about your health or the health of those around you!

Get the flu shot. Not the flu.

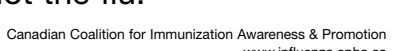

Les 10 raisons les plus absurdes de NE PAS vous faire vacciner contre l'influenza :

10. Vous pensez que les douleurs, la souffrance et la fièvre ont du bon

9. Vous adorez vous faire plaindre

8. Vous n'avez pas regardé de téléromans depuis une éternité

7. Vous voulez que vos collègues vous laissent un peu tranquille

6. Vous aimez avoir la voix rauque

5. Vous raffolez des frissons

4. Vous avez besoin de petites vacances

3. Vous avez des actions dans la compagnie Kleenex ${ }^{\circledR}$

2. Vous considérez qu'éternuer constitue un bon exercice physique

ET LA RAISON NO 1 LA PLUS ABSURDE DE NE PAS VOUS FAIRE VACCINER CONTRE L'INFLUENZA EST...

1. Vous ne vous préoccupez pas vraiment de votre santé, ni de celle de vos proches !

Oui au vaccin. Non à l'influenza.

Coalition canadienne pour la sensibilisation et la promotion de la vaccination 